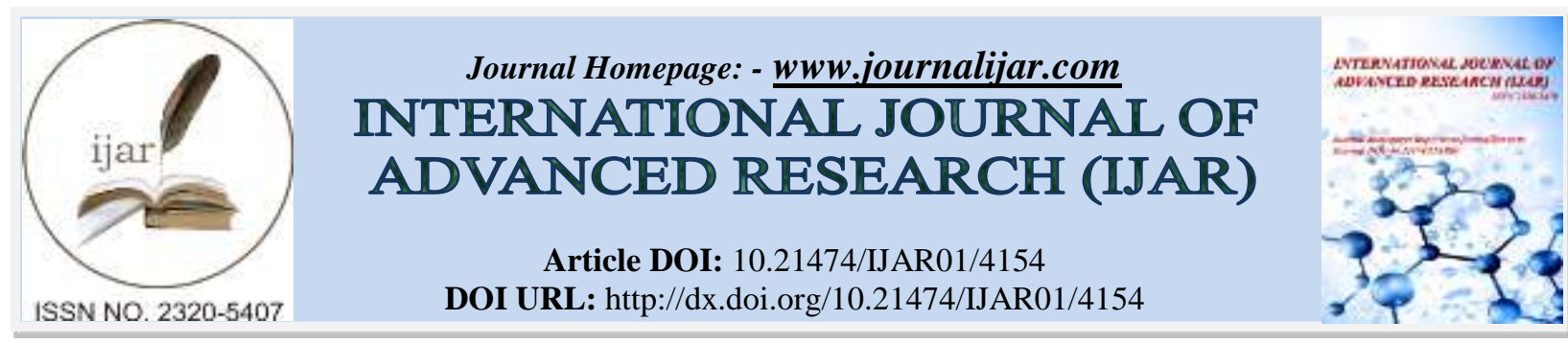

RESEARCH ARTICLE

\title{
ROLE OF HERBAL SUPPLEMENT IN FACILITATING OVULATION INDUCTION IN COWS SUFFERING FROM POST PARTUM ANOESTRUS.
}

\author{
Kamlesh Hadiya ${ }^{1}$, Anurag Borthakur ${ }^{2}$, Vikas Yadav $^{2}$ and K. Ravikanth ${ }^{2}$. \\ 1. Farm Consultant, College of Veterinary Science, Anand. \\ 2. R and D, Ayurvet Limited, Baddi, Himachal Pradesh.
}

\section{Manuscript Info}

Manuscript History

Received: 11 March 2017

Final Accepted: 16 April 2017

Published: May 2017

Key words:-

Conception rate, discharge, ovulation, post parturient anoestrus.

\begin{abstract}
A study was carried out to evaluate the efficacy of herbal formulation in inducing ovulation in cows suffering from post parturient anoestrus. A total of 18 cows suffering from post partum anoestrus were selected for the purpose of study and allotted into three different groups. Group T0 (n=6) was kept as control and fed standard diet. Group T1 (n=6) was treated with AV/OIP/22 @ 200g once daily along with standard diet. Group T2 (n=6) was treated with Brand A @ 200g once daily along with standard basal diet. Parameters viz. time taken for exhibition of estrus, nature of discharge pre and post treatment and conception rate were evaluated. Results revealed that there was significant increase in the no. of animals that exhibited estrus in the AV/OIP/22 treated group as compared to control. The conception rate was also found to be significantly higher in the AV/OIP/22 treated group T1 as compared to Brand A treated group T2. Thus, it can be inferred that AV/OIP/22 nis highly effective in inducing ovulation in animals suffering from post partum anoestrus.
\end{abstract}

Copy Right, IJAR, 2017,. All rights reserved.

\section{Introduction:-}

Reproductive performance is one of the most important factors determining the profitability of dairy herds. The failure of the modern-day dairy herds to achieve the optimal level of fertility is a major cause of reduced production efficiency for all various production systems (Opsomer and Crowe, 2014). The major limitation to the success of rebreeding after each calving is the presence of postpartum anestrus in the cow herd (Ahmadzadeh et al., 2011). The inability to detect oestrus and to mate the cows by 60 to 80 days after calving is a common problem among dairy farmers nowadays. It has been suggested that selection of cows for increased production may compromise reproductive performance by increasing prevalence of postpartum anoestrus or by reducing conception rates (Wheadon, 1993). The lack of ovulation of dominant follicles during the post-partum period is associated with infrequent luteinizing hormone ( $\mathrm{LH})$ pulses, with both suckling and low level of nutrition being implicated in the prolonged suppression of LH pulses in the absence of progesterone (Crowe, 2014). Income levels of farmers drastically reduce consequent upon lengthened calving intervals, lower / inputs or outputs / fixed costs ratios (Sol et al., 1984), reduced milk yield, loss of calf crop, increased labor etc (Bellows and Short, 1994). In view of the need to address the problem of post partum anoestrus which is widely prevalent across the country and takes a drastic toll on economy of dairy farmers, the current study has been undertaken t evaluate the efficacy of herbal ovulation inducers in reducing the instances of post partum anoestrus. 


\section{Materials And Methods:-}

Experimental design:-

A trial was carried out in an organized farm at Anand district of Gujrat to evaluate the efficacy of AV/OIP/22 (M/S Ayurvet Limited) in inducing ovulation in post partum anoestrus cows. A total of 18 cows suffering from post partum anoestrus were selected for the purpose of study and allotted into three different groups. Group T0 (n=6) was kept as control and fed standard diet. Group T1 $(\mathrm{n}=6)$ was treated with AV/OIP/22 @ 200g once along with standard diet. Group T2 (n=6) was treated with Brand A @ 200g once along with standard basal diet. Parameters viz. time taken for exhibition of estrus, nature of discharge pre and post treatment and conception rate were evaluated.

\section{Statistical Analysis:-}

The data collected was analyzed by applying standard statistical methods described by Snedecor and Cochran (1971)

\section{Results:-}

Estrous response and duration of estrus:-

The number of animals that exhibited estrus were significantly higher in the AV/OIP/22 treated group T1 (five animals out of six animals exhibited estrus) as compared to the control group T0 (two animals out of six animals exhibited estrus). There was, however, no difference in the average duration of estrus between the treated group and the control group (table 1).

Table 1:- Estrous response and duration of estrus in the treated animals

\begin{tabular}{|l|l|l|l|l|}
\hline Groups & No of animals & $\begin{array}{l}\text { No. of animals } \\
\text { Exhibited estrus }\end{array}$ & $\begin{array}{l}\text { Average } \\
\text { Percentage }\end{array}$ & $\begin{array}{l}\text { Average Duration } \\
\text { of estrus }\end{array}$ \\
\hline Control group T0 & 6 & 2 & $33.33 \%$ & $24 \mathrm{hrs}$ \\
\hline $\begin{array}{l}\text { AV/OIP/22 treated } \\
\text { group T1 }\end{array}$ & 6 & 5 & $83.33 \%$ & $16-24 \mathrm{hrs}$ \\
\hline $\begin{array}{l}\text { Brand A treated } \\
\text { group T2 }\end{array}$ & 6 & 6 & $100 \%$ & $12-24 \mathrm{hrs}$ \\
\hline
\end{tabular}

Time taken for exhibition of estrus:-

The time taken for exhibition of estrus was minimum in AV/OIP/22 treated group T1 with two animals exhibiting estrus on $3^{\text {rd }}$ day, two animals on $4^{\text {th }}$ day and one animal on $7^{\text {th }}$ day. However, in the control group, estrus by one animal was exhibited at a protracted length of $7^{\text {th }}$ day (table 2).

Table 2:- Time taken for exhibition of estrus

\begin{tabular}{|c|c|c|c|c|c|c|c|c|c|c|}
\hline \multirow[t]{2}{*}{ Group } & \multirow{2}{*}{$\begin{array}{l}\text { No. of } \\
\text { cows } \\
\text { exhibiting } \\
\text { estrus. }\end{array}$} & \multicolumn{8}{|c|}{ Time taken for exhibition of estrus } & \multirow{2}{*}{$\begin{array}{l}\text { Average } \\
\text { Time } \\
\text { taken for } \\
\text { exhibition } \\
\text { of } \\
\text { estrus } \\
\text { Mean S.E. }\end{array}$} \\
\hline & & $\begin{array}{l}1^{\text {st }} \\
\text { day }\end{array}$ & $\begin{array}{l}2^{\text {nd }} \\
\text { day }\end{array}$ & $3^{\text {rd }}$ day & $4^{\text {th }}$ day & $5^{\text {th }}$ day & $6^{\text {th }}$ day & $7^{\text {th }}$ day & $8^{\text {th }}$ day & \\
\hline $\begin{array}{l}\text { Control } \\
\text { group T0 }\end{array}$ & 2 animals & - & - & $\begin{array}{l}\text { One } \\
\text { animal } \\
\text { shows } \\
\text { estrus } \\
\text { on } 3^{\text {rd }} \\
\text { day }\end{array}$ & - & - & - & $\begin{array}{l}\text { One } \\
\text { animal } \\
\text { shows } \\
\text { estrus } \\
\text { on } 7^{\text {th }} \\
\text { day }\end{array}$ & - & $\begin{array}{l}5.00 \pm 0.00 \\
\text { days }\end{array}$ \\
\hline $\begin{array}{l}\text { AV/OIP } \\
\text { treated } \\
\text { group } \mathrm{T} 1\end{array}$ & 5 animals & - & - & $\begin{array}{l}\text { Two } \\
\text { animals } \\
\text { show } \\
\text { estrus } \\
\text { on } 3^{\text {rd }} \\
\text { day }\end{array}$ & $\begin{array}{l}\text { Two } \\
\text { animals } \\
\text { show } \\
\text { estrus } \\
\text { on } 4^{\text {th }} \\
\text { day }\end{array}$ & - & - & $\begin{array}{l}\text { One } \\
\text { animal } \\
\text { shows } \\
\text { estrus } \\
\text { on } 7^{\text {th }} \\
\text { day }\end{array}$ & - & $\begin{array}{l}4.00 \pm 0.00 \\
\text { days }\end{array}$ \\
\hline Brand $\mathrm{A}$ & 6 & - & - & Two & One & One & One & - & One & $4.83 \pm 3.33$ \\
\hline
\end{tabular}




\begin{tabular}{|c|c|c|c|c|c|c|c|}
\hline $\begin{array}{l}\text { treated } \\
\text { group T2 }\end{array}$ & animals & $\begin{array}{l}\text { animals } \\
\text { show } \\
\text { estrus } \\
\text { on } 3^{\text {rd }} \\
\text { day }\end{array}$ & $\begin{array}{l}\text { animal } \\
\text { shows } \\
\text { estrus } \\
\text { on } 4^{\text {th }} \\
\text { day }\end{array}$ & $\begin{array}{l}\text { animal } \\
\text { shows } \\
\text { estrus } \\
\text { on } 5^{\text {th }} \\
\text { day }\end{array}$ & $\begin{array}{l}\text { animal } \\
\text { shows } \\
\text { estrus } \\
\text { on } 6^{\text {th }} \\
\text { day }\end{array}$ & $\begin{array}{l}\text { animal } \\
\text { shows } \\
\text { estrus } \\
\text { on } 8^{\text {th }} \\
\text { day }\end{array}$ & days \\
\hline
\end{tabular}

\section{Nature of discharge:-}

The nature of discharge post treatment period in control group T0 and AV/OIP/22 treated group T1 was clear with clear mucus hanging from the vulva. There was no discernable difference in the nature of discharge between the control group T0 and the AV/OIP/22 treated group T1. However in the Brand A treated group, the elasticity and viscosity of mucus is less as compared to the control group T0 and AV/OIP treated group T1 (table 3).

Table 3:- Nature of discharge

\begin{tabular}{|l|c|c|l|}
\hline Groups & No. of animals & $\begin{array}{l}\text { No. of animals exhibiting } \\
\text { estrus }\end{array}$ & Nature of discharge \\
\hline Control group T0 & 6 & 2 & $\begin{array}{l}\text { Clear discharge with ropy } \\
\text { mucous hanging from the } \\
\text { vulva }\end{array}$ \\
\hline Control group T1 & 6 & 5 & $\begin{array}{l}\text { Clear discharge with ropy } \\
\text { mucous hanging from the } \\
\text { vulva }\end{array}$ \\
\hline Control group T2 & 6 & 6 & $\begin{array}{l}\text { Clear discharge with ropy } \\
\text { mucous hang from the } \\
\text { vulva, But the elasticity } \\
\text { and viscosity is } \\
\text { comparatively less }\end{array}$ \\
\hline
\end{tabular}

\section{Conception rate:-}

In the control group T0, two animals conceived after A.I. In the AV/OIP/22 treated group T1, 5 animals showed estrus and four animals conceived after A.I. In the Brand A treated group T2, six animals showed estrus and four animals conceived after A.I. The conception rate was higher in the AV/OIP/22 treated group T1 as compared to the control and comparable with Brand A treated group T2 (table 4).

Table 4:- Conception rate of the control and treated groups

\begin{tabular}{|l|c|c|l|}
\hline Groups & No. of animals & No. of animals conceived & Conception \% \\
\hline Control group T0 & 6 & 2 & $33.33 \%$ \\
\hline $\begin{array}{l}\text { AV/OIP/22 treated group } \\
\text { T1 }\end{array}$ & 6 & 4 & $66.66 \%$ \\
\hline Brand A treated group T2 & 6 & 4 & $66.66 \%$ \\
\hline
\end{tabular}

\section{Discussion:-}

Citrullus colocynthus, a constituent ingredient of AV/OIP/22 is a rich source of flavonoids (Benariba et al., 2013), isovitexin (Akhzari et al., 2015), cucurbitans (Hatam et al., 1989) and caffiec acid (Shokrzadeh et al., 2013). The improvement in the esrus response may be attributed to caffiec acid which is known to inhibit nuclear factor kappa B (Akyol et al., 2015), a transcription factor which brings about changes in m- RNA synthesis and have a negative effect on reproductive performance. (Manimaran et al., 2016). A substantial body of research has pointed towards a

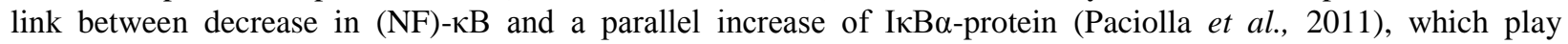
important and conserved roles in immune and stress responses (Oeckinghaus et al., 2009) and indirectly influence bovine reporduction. The improved estrus response may have also been brought about by the presence of flavonoids which are known to possess anti-oxidant property (Pietta, 2000) and improve reproductive health (Lessera et al., 2015). Presence of isovitexin may also have played a significant role in bolstering estrus response as it is known to possess free radical scavenging activity (Khole et al., 2016) and neutralize the peroxy free radicals that hamper the proper functioning of the reproductive organs (Agrawal et al., 2005). Numerous studies have also shown that there is significant influence of inflammation on follicular development and function postpartum (Sheldon et al., 2002). Lipopolysaccharides from bacteria such as E.Coli suppress the release of LH by the pituitary (Sheldon et al., 2009), 
which in turn leads to a smaller diameter of postpartum ovarian dominant follicles and as a consequence resulting in lower plasma estradiol levels. Cucurbitans, a phytochemical present in Citrullus colocynthus, is known to possess significant anti inflammatory property (Peters et al., 1997) and act via suppression of TNF- $\alpha$-induced inflammatory cytokines production interleukin-1 $\beta$ (IL-1 $\beta$ ), interleukin-6 (IL-6), and interleukin-8 (IL-8) mRNA and protein expression in human synoviocyte MH7A cells (Jia et al., 2015). Zingiber officinale, also a constiturnt ingredient of AV/OIP/22 is known to possess anti-oxidant property (Ghasemzadeh et al., 2010) and may aid in onset of ovulation in cows suffering from post partum anoestrus.

\section{Conclusion:-}

Administration of polyherbal formulation to the cows suffering from post partum anoestrus is effective in hastening the onset of estrous in those cows and also increase the chances of conception.

\section{Acknowledgement:-}

The authors are thankful to Ayurvet Limited, Baddi, India and Organized Veterinary farm at Anand, Gujrat for providing the facilities required for the trial.

\section{Reference:-}

1. Opsomer G, Crowe ME. (2004) Post partum anoestrus in the high yielding dairy cows. Vlaams Dier ge nees kun dig Tijd schrift 73:112-118.

2. Ahmadzadeh A, Carnahan K, Autran, C. (2011) Understanding puberty and postpartum anestrus. Applied Reproductive Strategies in Beef Cattle. Department of Animal \& Veterinary Sciences, University of Idaho, Moscow.

3. Wheadon MC. (1993) The relationship between breeding index and conception rate and the cost of delayed conception. Proceedings of the New Zealand Society of Animal Production 53: 41-42.

4. Sol J, Stelwagen J, Dijkhuizen A (1984). A three year herd health and management program on thirty Dutch dairy farms. 11. Culling strategy and losses caused by forced replacement of dairy cows. Vet. Quart, 6 (3): 149157.

5. Bellows RA, Short RE (1994). Reproductive losses in the beef industry. In Factors Affecting Calf Crop. Fields and Sands (Ed.). p109. (CRC Press, Boca Raton, FL.).

6. Snedecor GW, Cochran WG. Statistical methods ( $7^{\text {th }}$ eds.) IOWA: IOWA state, university press; 1, 1971, 503.

7. Benariba N, Djaziri R, Bellakhdar W, Belkacem N, Kadiata M, Malaisse WJ, Sener A. (2013). Phytochemical screening and free radical scavenging activity of Citrullus colocynthis seed extract. Asian Pac J Trop Biomed 3(1): $35: 40$.

8. Akhzaru M, Mirghiasi M, Vassaf M, Bidgoli MSM, Tari ZS. (2015). The effect of Citrullus colocynthis on the reduction of inflammatory agents in osteoarthritis. Mol Biol 4:4.

9. Hatam AR, Whiting A, Yousif NJ. (1989). Cucurbitacin glycocydes feom Citrullus colocynthis. Phytochemistry 28(4): $1268-1271$.

10. Shokrzadeh M, Chabra A, Naghshvar F, Ahmadi A. (2013). The mitigating effect of Citrullus colocynthis fruit extract against genotoxicity induced by cyclophosmamaide in mice bone marrow cells. The scientific world journal.

11. Akyil S, Akbas A, Butun I, Toktas M, Ozyurt H, Sahin S, Aky O. (2015). Caffeic acid phenethyl ester as a remedial agent for reproductive functions and oxidative stress based pathologies of gonads.

12. Manimaran A, Kumaresan A, Jeyakumar S, Mohanty TK, Sejian V, Kumar N, Sreela L, Prakash MA, Mooventhan P, Anantharaj A, Das DN. (2016). Potential of acute phase proteins as predictor of post partum uterine infections during transition periods and its regulatory mechanism in dairy cattle. Vet world 9(1): 91-100.

13. Paciolla R, Fusco BF, Pescatore A, Poeta L, Ursini MV, Lioi MB, Miano MG. (2011). Nuclear factor-kappa-Binhibitor alpha (NFKBIA) is a developmental marker of $\mathrm{NF}-\mathrm{kB} / \mathrm{p} 65$ activation during in vitro oocyte maturation and early embryogenesis. Human Reprod. 26(5): 1191-1201.

14. Oeckinghaus A., Ghosh S. (2009). The NF-кB Family of Transcription Factors and Its Regulation. Cold spring harb perspect boil. 1(4): 34 .

15. Pietta PG. (2000). Flavonoids as antioxidants. J Nat Prod. 63(7): 1035-42.

16. Lessera NR, Carl L, Lanoue KL. (2015). Reproductive and developmental outcomes, and influence onmaternal and offspring tissue mineral concentrations, of $(-)$-epicatechin, $(+)$-catechin, and rutin ingestion prior to,and during pregnancy and lactation in C57BL/6J. Toxicology Reports 2 : 443-449. 
17. Khole S, Panat NA, Suryawanshi P, Chatterjee S, Ghaskadbi S. (2016). Comprehensive assessment of antioxidant activities of apigenin isomers: Vitexin and isovitexin. Free Radicals and antioxidants 6(2): 155-166.

18. Agarwal A, Gupta S, Sharma RK. (2005). Role of oxidative stress in female reproduction. 3: 28.

19. Sheldon, I.M., Noakes, D.E., Rycroft, A.N., Pfeiffer, D.U. \& Dobson, H. (2002). Influence of uterine bacterial contamination after parturition on ovarian dominant follicle selection and follicle growth and function in cattle. Reproduction (Cambridge, England) 123 (6): 837-845.

20. Sheldon I, Cronin IM, Goetze J, Donofrio L, Schuberth HJ. (2009). Defining postpartum uterine disease and the mechanisms of infection and immunity in the female reproductive tract in cattle, Biology of reproduction. 81 (6): 1025-1032.

21. Peters RR, Farias MR, Ribeiro-do-Valle RM. (1997). Anti-inflammatory and analgesic effects of cucurbitacins from Wilbrandia ebracteata. Plant med. 63(6): 525-528.

22. Jia Q, Cheng W, Yue Y, Hu Y, Zhang J, Pan X, Xu Z, Zhang P. (2015). Cucurbitacin inhibits TNF- $\alpha$-induced inflammatory cytokineproduction in human synoviocyte MH7A cells via suppression of PI3K/Akt/NF-kB pathways. International immunology. 29: 884-890.

23. Ghasemzadeh A, Jaafar HZE, Rahmat A. (2010). Antioxidant activities, total phemnolics and flavonoid content in two varieties of Malaysia young ginger (Zingiber officinals). Molecules 15: 4324-4333. 